\title{
On the Category of Speaker Expectation of Interlocutor Knowledge in Kurtöp
}

\author{
GWENDOLYN HYSLOP \\ Australian National University ${ }^{1}$
}

\section{$1 \quad$ Introduction}

Kurtöp is an under-described and threatened Tibeto-Burman language of Northeastern Bhutan, spoken by approximately 15,000 native speakers. Existing literature on Kurtöp has described a complex and fascinating system of epistemic contrasts, involving mirativity, egophoricity, evidentiality, and other related categories (e.g. Hyslop 2011a; 2011b; 2014a). The aim of this article is to bring into focus one of the most unique aspects of this system -- that is, the contrast of speaker expectation of interlocutor knowledge. As I will show, Kurtöp grammar requires speakers to anticipate the knowledge status of their interlocutors in the following grammatical contexts: perfective aspect, tags, and questions. This contrast is unlike evidentiality (source of knowledge) but perhaps related to mirativity (expectation of knowledge) and appears to be undescribed elsewhere in the literature. That is, this article proposes a new typological category based on data from Kurtöp: the category of speaker expectation of interlocutor knowledge.

The discussion begins in $\$ 2$ with background information on Kurtöp and a presentation of the relevant definitions. The next three sections present the Kurtöp data, with $\S 3$ focusing on perfective aspect, $\S 4$ focusing on the tag particles, and $\S 5$ discussing question formation. A summary and conclusion is offered in $\S 6$.

\section{Background}

\subsection{Kurtöp}

Kurtöp belongs to the East-Bodish sub-branch of the Tibeto-Burman family. East Bodish languages have been described as close relatives of Tibetan, but constitute a sub-branch in their own right (e.g. Hyslop 2014b). Like most Tibeto-Burman languages Kurtöp has verb-final syntax. Core arguments generally precede the verb and in the case of bivalent verbs, the A argument will precede the $\mathrm{O}$ argument. However, this AOV order is a generalization; in natural speech arguments may follow the verb, depending on pragmatic factors. Verbal arguments are not required overtly and, in fact, are often missing in natural discourse.

Kurtöp clauses can be broadly divided into two categories: those that end in a copula and those that end with a finite-marked verb. For those constructions in the former category, a copula

1 This research has been generously funded by the Endangered Languages Documentation Project, the National Science Foundation, and the Association for Asian Studies. Within Bhutan, the Dzongkha Development Commission has given permission and support for this research. I am grateful to many people for discussion of the Kurtöp data and its typological implications, including Karma Tshering, Kuenga Lhendup, Scott DeLancey, Nicholas Evans, Sasha Aikhenvald, Bob Dixon, Judith Tonhauser, Roberto Zariquiey, and the rest of the BLS40 audience, in general. I retain responsibility for any errors. 
may be used to encode typical copular functions (existence, equation, prediction, location, possession), may be used in conjunction with a clausal nominalization or may be used with a non-final marked converb in the clause-chaining construction. Clauses that do not end in a copula will consist of minimally a verb plus a finite suffix.

Verbs are usually composed of two to three morphemes within three to four syllables and it is not unusual for verbs to consist of five syllables. There is one prefix in the language (the negative marker) and the remainder of verbal morphology comprises suffixes and enclitics. A verb stem is almost always monosyllabic. Any stem can be negated and can take any of the mutually exclusive suffixes (though not all suffixes can co-occur with the negative marker). There are four enclitics which speakers can use at the end of the clause, so that they would be attached to a copula, in the case of a copular clause, or attached to the end of the finite-marked verb, in the case of a copula-less clause. The examples below show the hearsay enclitic attached to a finite verb in $(1)^{2}$, and to a copula in (2).

$$
\begin{aligned}
& \text { khit geshangri } \\
& {[\mathrm{khit} \text { ge-shang]=ri }} \\
& \text { 3.ABS go-PFV.EGO=HSY } \\
& \text { '(I heard that) he went.' }
\end{aligned}
$$

(2) khit gewala wentari

[khit ge-pala wenta] $=$ ri

3.ABS go-NMZ:PFV COP.EQ.MIR=HSY

'(I heard that) he went indeed!'

Kurtöp has a very complex mirative/evidential/epistemic system and the contrasts described in this article play a small role in the system at large. Various aspects of the system have been described in Hyslop (2011b, to appear) and the system as a whole is presented in (2014a). The aim of this article is to focus on what I argue is a category distinct from evidentiality and mirativity -- the category of speaker anticipation/expectation of interlocutor knowledge. Data presented in this article will be at first introduced as part of the paradigmatic system to which they belong before expanding on use.

The approximate location of the Kurtöp speech community is shown in Figure 1. The majority of examples presented here come from natural data collected during fieldwork conducted in Bhutan between 2006 and 2013. Most examples are drawn from a database consisting of transcribed narratives and conversations from over ten speakers, males and females, ranging in age from early twenties to seventies.

2 Data are presented in a Romanized orthography as follows: $<\mathrm{k}>[\mathrm{k}],<\mathrm{kh}>\left[\mathrm{k}^{\mathrm{h}}\right],<\mathrm{g}>[\mathrm{g}],<\mathrm{ng}>[\mathrm{g}],<\mathrm{c}>[\mathrm{c}],<\mathrm{ch}>$ $\left[\mathrm{c}^{\mathrm{h}}\right],<\mathrm{j}>[\mathrm{f}],<\mathrm{ny}>[\mathrm{n}],<\mathrm{tr}>[\mathrm{t}],<\mathrm{thr}>\left[\mathrm{t}^{\mathrm{h}}\right],<\mathrm{dr}>[\mathrm{d}],<\mathrm{t}>[\mathrm{t}],<\mathrm{th}>\left[\mathrm{t}^{\mathrm{h}}\right],<\mathrm{d}>[\mathrm{d}],<\mathrm{p}>[\mathrm{p}],<\mathrm{ph}>\left[\mathrm{p}^{\mathrm{h}}\right],<\mathrm{b}>[\mathrm{b}],<\mathrm{m}>[\mathrm{m}]$, $<\mathrm{ts}>[\mathrm{ts}],<\mathrm{tsh}>\left[\mathrm{ts}^{\mathrm{h}}\right],<\mathrm{sh}>[\mathrm{c}],<\mathrm{zh}>[\mathrm{j}],<\mathrm{s}>[\mathrm{s}],<\mathrm{z}>[\mathrm{z}],<\mathrm{l}>[\mathrm{l}],<\mathrm{lh}>[\mathrm{l}],<\mathrm{r}>[\mathrm{r}],<\mathrm{a}>[\mathrm{a}],<\mathrm{e}>[\mathrm{e}],<\mathrm{i}>[\mathrm{i}],<\mathrm{0}>[\mathrm{o}]$, $<\mathrm{u}>[\mathrm{u}],<\ddot{\mathrm{o}}>[\varnothing],<\ddot{\mathrm{u}}>[\mathrm{y}],<^{\prime} \mathrm{CV}>$ high tone on following vowel, $<\wedge>$ long vowel. 


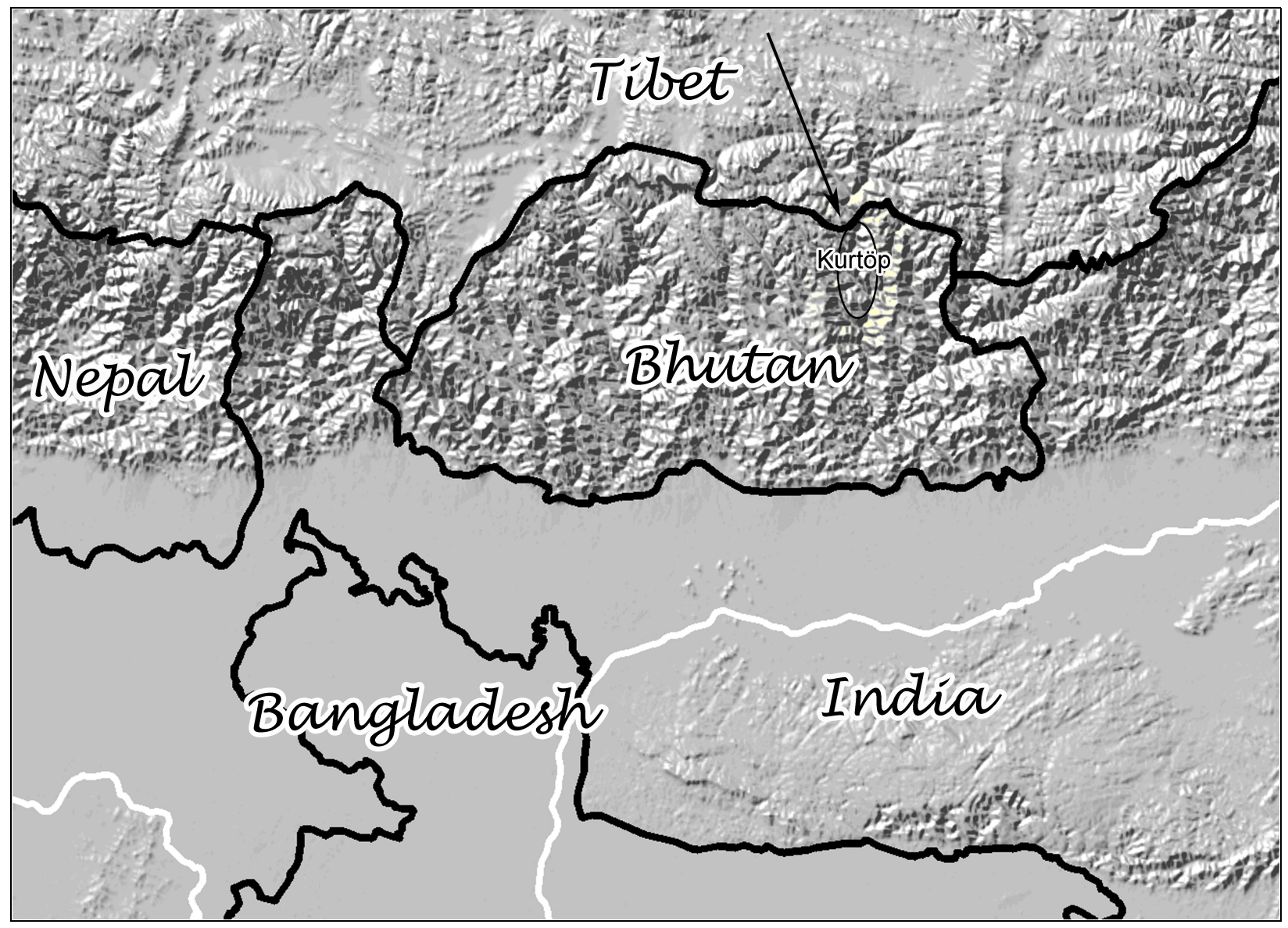

Figure 1. Kurtöp language area

\subsection{Definitions}

As this article argues for a previously undescribed linguistic category, it will be useful to begin with some terminology used to designate related categories. Evidentiality, which has received substantial attention in the literature, is the grammaticalized encoding of information source (Aikhenvald 2004:14). A related but distinct category is that of mirativity, described by DeLancey (1997) as 'the status of the proposition with respect to the speaker's overall knowledge structure'. In Hyslop (2011b) I define mirativity as encoding expectation of knowledge. The term 'egophoric' is used to describe a related category but has received less attention in the literature. For our purposes, we can use Tournadre (2008) as a starting point; he describes egophoric as expressing 'personal knowledge or intention on the part of the actual speaker' (2008:295). He goes on to describe a contrast between narrow and broad scope of egophorics and it appears the narrow scope is most similar to the Kurtöp category. The precise nature of the Kurtöp 'egophoric' will become clearer as we proceed. 
Kurtöp makes a five-way contrast in perfective aspect, as summarized in Figure 2. This analysis has been put forth in other publications, including Hyslop (2011b; 2014; to appear) but is updated slightly here.



Figure 2. Kurtöp perfective aspect markers

The five forms can be understood as follows. If a speaker is not certain of the knowledge they are conveying, the form -para will be used. If a speaker is certain of the knowledge, further contrasts are made. For contexts in which the speaker gained their evidence indirectly, through inference, the indirect evidential form - $m u$ will be used. If the speaker has direct evidence but was not anticipating the event, the mirative form $-n a$ will be used. When the speaker has no basis to use the mirative but is certain and gained evidence for the event directly, a two-way contrast is made. For contexts in which the speaker has exclusive access to knowledge the form -shang will be used while in non-exclusive contexts the form -pala will be used. This contrast will be the focus of the next two sections.

\section{1 -shang}

Kurtöp -shang is used to encode perfective aspect with direct evidential value when the speaker has direct evidence of the experience and there is no expectation that the interlocutor would have 
direct evidence. This is usually used with first person arguments and is given as the default form for perfective first person utterances in elicitation. For examples from natural speech, consider (3) and (4):

(3) khici mengya zhit geshang

khici meng=ya zhit ge-shang

3.GEN name $=$ also forget go-PFV.EGO

'(I) also forgot his name.'

(4) Paroko yumgi ngâ zonshangmi

$\begin{array}{llll}\text { Paro=ko } & \text { yum=gi } & \text { ngak } & \text { zon-shang=mi } \\ \text { Paro=LOC } & \text { mother.HON=ERG } & \text { do } & \text { send-PFV.EGO=TAG.EXCL }\end{array}$

'The mother sent (me) to Paro.'

Both examples are statements uttered from one speaker to an interlocutor who would not already have the knowledge. In the case of (3), the speaker realized mid-narration that she had forgotten the name of a particular character in a story. The act of forgetting is very much a personal experience by default and thus the use of -shang would be expected; the speaker clearly has exclusive access to this knowledge without any expectation her interlocutor would share her lack of remembrance. Example (4) is slightly different in nature. Sending something is not intrinsically personal in the same way forgetting is but in this particular context two speakers who had not previously known each other were engaged in conversation. One speaker was relaying an experience he had while working for a Rimpoche in Bhutan and this information was new to the interlocutor. In both (3) and (4), the speakers themselves were also actors/patients and the interlocutor did not previously have access to the knowledge.

However, -shang is not limited to first person arguments; it can also be used for third person when the speaker has privileged access to the knowledge. Consider (5):

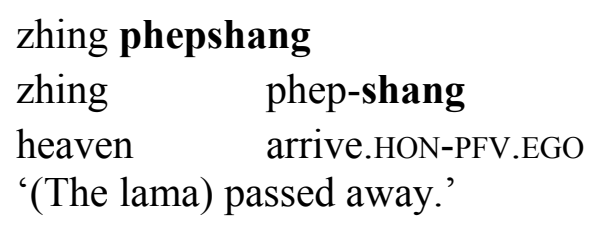

This example comes from the same conversation as (4). The speaker had worked for a lama for some time and was closely associated with the lama's life and ultimate death. The interlocutor had heard of the lama but did not know him personally and did not know he had passed away. The speaker uses -shang in this case because of his privileged access to knowledge about the lama.

Examples with second person are rare, but not impossible, as in (6):

(6) da wit boishang, gilu 


$\begin{array}{llll}\text { da } & \text { wit } & \text { boi-shang } & \text { ge-lu } \\ \text { now } & \text { 2.ABS } & \text { recover-PFV.EGO } & \text { go-IMP }\end{array}$

'Now you are recovered; go.'

The context for (6) is a conversation between a doctor and a patient. The patient had spent some time in the hospital being treated for an illness. The doctor who had treated the patient had privileged access to knowledge of the patient's health while the patient himself was ignorant. Once the doctor had successfully treated the patient he uttered (6). Even though the statement is in reference to second person, the form -shang is used because the speaker had exclusive access to knowledge which was not shared with the interlocutor.

\section{2 - pala}

Like -shang, Kurtöp - pala (with allomorphs -wala and -sala) encodes speaker certainty and direct evidence. However, in contrast to -shang, -pala does not encode exclusive access to knowledge; rather, it entails an expectation that someone else also has direct knowledge of the event. Thus, this form usually occurs with second or third person and is given as the default second and third person perfective form in elicitation. Two examples from natural discourse are shown in (7) and (8) .
dutshot matshangwala
dutshot ma-tshang-pala
time NEG-be.complete-PFV
'The time wasn't up'

$$
\begin{aligned}
& \text { Nya Gompa la 'lepsong sungwalari Guru Rimpochegi } \\
& \text { Nya Gompa la 'lepsong sung-pala=ri Guru Rimpoche=gi } \\
& \text { Nya Temple LOC arrived say.HON-PFV }=\text { HSY Guru Rimpoche }=\text { ERG } \\
& \text { “'(It) arrived at Nya Temple”, Guru Rimpoche said.' }
\end{aligned}
$$

Example (7) comes from a narrative, evidencing a canonical use of -pala. The speaker, engaged in story-telling and not sharing personal experience, does not have exclusive access to the knowledge at hand and thus uses -pala rather than -shang. The same can be said of (8); the speaker is telling a story and does not have exclusive access to the knowledge at hand.

While -pala usually occurs with third person referents, it can occur with first person referents if the interlocutor has direct knowledge of the event, as in (9).

tshachu bang niye 'yaura drâ ngak lappala ngai

$\begin{array}{lllllll}\text { tshachu bang } & \text { ni-le } & \text { 'yau=ra } & \text { drak } & \text { ngak } & \text { lap-pala } & \text { ngai } \\ \text { hotsprings bathe } & \text { stay-IMP } & \text { UP=EMPH } & \text { be.good } & \text { QUOT } & \text { tell-PFV } & \text { 1.ERG }\end{array}$

3 Note that the locative marker la and subordinate verb 'lepsong are both borrowings from Tibetan. 
“'Stay in the hot springs up there; it is good", I said.'

Perhaps not surprisingly, -pala is often used with first person plural referents. In such contexts, the speaker, obviously, usually does not have exclusive access to knowledge as the event was shared with another person. As a result, -shang would be less appropriate. Example (10), drawn from an interview with two elderly speakers, illustrates -pala with a first plural referent.

neci gangna woso kau chutpala

neci gang=na woso kau chut-pala

1.PL.EXCL.GEN time $=$ LOC like.that pillar cut-PFV

'How difficult it was in our time! (lit. how we cut pillars in our time)'

In short, the difference between -shang and -pala is whether or not the speaker has privileged or exclusive access to knowledge.

\section{$4 \quad$ Enclitics}

In addition to encoding evidentiality or evidential-like categories throughout the verbal and copular paradigm, Kurtöp has several enclitics that encode related categories. One clitic, $=r i$, is an evidential, marking oral source of knowledge. Another clitic, $=s a$, marks that an event or the result of an event was counter to expectation. The final two clitics are tags, differing by whether or not the speaker expects the interlocutor to share the knowledge. These four clitics are summarized in Table 1 and the remainder of this section discusses the difference between the two tags.

\begin{tabular}{|l|l|}
\hline ENCLITIC & VALUE \\
\hline$=r i$ & Hearsay \\
\hline$=s a$ & Counter Expectation \\
\hline$=\boldsymbol{m} \boldsymbol{i}$ & Tag.EXC \\
\hline$=\boldsymbol{w} \boldsymbol{u}$ & Tag.INCL \\
\hline
\end{tabular}

Table 1. Verbal clitics

\subsection{Exclusive Tag $=m i$}

As with other tags, the primary function of $=m i$ is to involve the interlocutor into the conversation, seeking a response or agreement. However, in using tags, Kurtöp speakers are required to take into account the state of knowledge of their interlocutor. The tag $=m i$ is chosen for the contexts in which the speaker does not anticipate the interlocutor to already share the knowledge, for example if the speaker is relaying novel information or telling a story. Some examples will help elucidate this further. 
The exclusive tag $=m i$ is common in conversation between two strangers getting to know each other. Both (11) and (12) are drawn from a conversation between two people getting to know each other. The speaker in (11) and (12) is relaying information about mutual acquaintances back in Bhutan, realizing his interlocutor does not already have knowledge about these particular events. Thus, when choosing a tag he uses $=m i$.

(11) hapta zonbakti nishangmi ngai tamo

hapta zon-bakti ni-shang=mi ngai ta-mo

week two-APPROX stay-PFV.EGO=TAG.EXC 1.ERG see-CTM

'He stayed about two weeks, right, in my opinion.'

(12) tshe khit nya thungmo nya zhiknami

$\begin{array}{lllll}\text { tshe } & \text { khit } & \text { mya thung-mo } & \text { mya zhik-na=mi } \\ \text { DM } & \text { 3.ABS } & \text { arrow do-CTM } & \text { arrow } & \text { be.hit-PFV.MIR=TAG.EXC }\end{array}$

'While playing archery he was hit by an arrow, right.'

Not surprisingly, =mi is a common tag in story-telling, bringing the speaker into the discourse but with the assumption they do not already share the knowledge. Example (13) is a typical introduction of something new in a story. Here, the exclusive tag attaches to the mirative copula wenta.

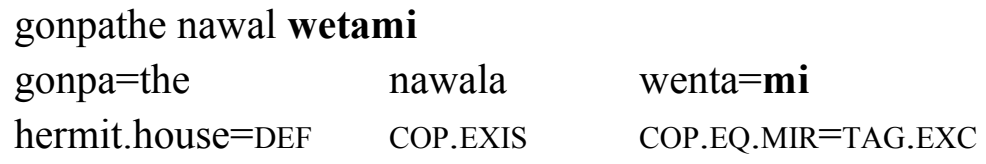

'There was this hermit house, right.'

Another typical use is explaining a procedure to someone who is unfamiliar. Example (14) comes from a procedural narrative, where the speaker is explaining to the foreign interlocutor how rice is farmed in the village. In general, the tag $=m i$ is used with people the speaker does not know well.

\section{(14) asu dar ciktami}

$\begin{array}{lll}\text { asu dara } & \text { cik-ta }=\text { mi } \\ \text { asu (rice type) now } & \text { be.beaten-IPFV.MIR=TAG.EXC }\end{array}$

'Asu is being beaten right now, right.'

\subsection{Inclusive Tag $=w u$}

Like other tags, $=w u$ (dialectal variant $a u$ ) bring the interlocutor into the conversation, often resulting with the interlocutor nodding or vocalizing an agreement. However, the use of $=w u$ is re- 
stricted to contexts in which the speaker expects the interlocutor to share his/her knowledge. Not surprisingly, this form is used frequently between people who know each other well.

Consider (15):
dakpa wenau neriki
Dakpa wen $=\mathbf{a u}$
neri-ki
Dakpa COP.EQ $=$ TAG.INCL
1.INCL.GEN-GEN
'Ours is Dakpa, right?'

This example was drawn from an interview between two people from the same village. They were discussing the various types of rice grown in the village and the speaker frequently uses the tag $=a u$ (variant of $w u$ ) during the conversation. She uses the tag to bring the interlocutor into the conversation, asking for agreement, but chooses $=a u$ because she knows her interlocutor already shares the knowledge.

The next two examples come from a conversation between two speakers who are getting to know each other the first time. They realize they are from the same region in Bhutan and begin discussing the area. One speaker utters (16), using the inclusive form of the tag, because he now knows his interlocutor shares the knowledge.

\section{(16) Tangmachu gesai yamna Chazam wenwu}

$\begin{array}{lllll}\text { Tangmachu } & \text { ge-sa=gi } & \text { yam=na } & \text { Chazam } & \text { wen=wu } \\ \text { Tangmachu } & \text { go-NMZ:PL=GEN } & \begin{array}{l}\text { road=LOC } \\ \text { Chazam }\end{array} & \text { COP.EQ=TAG.INCL } \\ \text { 'On the way to Tangmachu, it's Chazam, right.' } & & \end{array}$

The data in (17) are from a similar context, though this time the speaker is drawing from his knowledge that the interlocutor is also familiar with Bhutanese and American culture. The speakers are discussing dogs in America and comparing them to dogs in Bhutan. In the latter, dogs are most commonly stray and found begging in the streets. They are dirty, uncared for, and may have rabies. This is a very different life compared to an American dog, which is often very well cared for, to the extent there are places devoted for dog food, dog toys, people to walk the dog, and so on. According to Bhutanese Buddhist belief, dogs are born as such in Bhutan because they have committed sins in their past lives and thus have to suffer as a Bhutanese dog in this life. American dogs, on the contrary, have such a pleasant life that (17) is a sensible explanation. Note again the use of the inclusive tag $=w u$ as the speaker knows his interlocutor shares this unique view of the world.

(17) khwi gap le daknawu

khwi gapo le dak-na=wu

$\operatorname{dog} \quad$ PL.FOC sins be.cleansed-PFV.MIR $=$ TAG.INCL

'The dogs have been cleansed of their sins, right?' 
The above examples provide a few contexts for when $=m i$ versus $=w u$ is used, though several others could be offered as these tags are very common in the discourse. They may take on particular pragmatic overtones in use which warrant further study. For example, use of $=m i$ with someone who does share knowledge of the event is considered sarcastic and can be offensive. Speakers will occasionally self-correct from $=m i$ to $=w u$, presumably realizing their interlocutor may, in fact, share their knowledge.

\section{Question Particles}

Question particles also intersect with the category that marks speaker expectation of interlocutor knowledge. Question formation in Kurtöp is complex, involving various suffixes and particles depending on the grammatical context (cf. Hyslop 2011a for a full description). For our purposes here, it will suffice to summarize by stating that a range of particles are used when the speaker expects the interlocutor to have the answer while the particle shu 'QP:DBT' will be used when the speaker does not expect the hearer to have the answer. These particles are discussed below.

\subsection{Expected}

The default question constructions in Kurtöp are for contexts in which the speaker expects the interlocutor to have the answer; these form the majority of questions in the language. For example, when asking a wh- question, the particle yo will be used. An example is (18):

$\begin{array}{llllll}\text { zhunggi dazin ngâko matshunani zhâ ngaksi bretak yo ngaksi } & & \\ \text { zhungg=gi } & \text { dazin } & \text { ngak-to } & \text { ma-tshuk-nani } & \text { zhâ } & \text { ngak-si } \\ \text { government=ERG } & \text { care } & \text { do-INF } & \text { NEG-be.able-COND } & \text { what } & \text { do-NF } \\ \text { blek-taki } & \text { yo } & \text { ngaksi } & & & \\ \text { keep-IPFV } & \text { QP } & \text { QUOT } & & & \end{array}$

'The government (says) 'If you aren't able to care for (the dog) then why keep (it)?'

The speaker in this example takes the point of view of the government asking someone about their dog. The default expectation here is that a dog's owner would be expected to have the answer the question.

Polar questions, depending on the grammatical context, require the particle $y a$, as in (19):

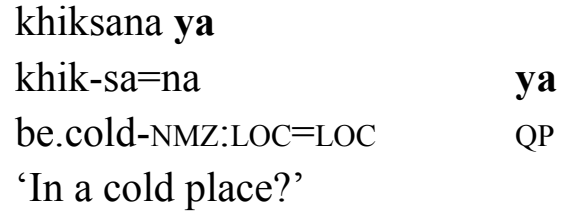

The description here is a somewhat simplified presentation of question formation in Kurtöp. For further details refer to Hyslop (2011a) but for our purposes let it suffice that when 
speakers anticipate their interlocutors to have the answer, they will use question particles as described above. This situation contrasts with the contexts in which the speaker does not have this expectation, as discussed immediately below.

\section{$5.2 \quad$ Unexpected}

When the speaker does not expect the hearer to know the answer, for example when asking a rhetorical question, the speaker replaces the question particle (regardless of what it is) with shu. However, shu is not simply used for rhetorical questions. The speaker must take into account the interlocutor's knowledge of the situation and determine whether or not shu would be appropriate. Example (20) is drawn from the texts:

$\begin{array}{lllll}\text { ngaita zhâ lapmal shu da? } & & & \\ \text { ngai-ta } & \text { zhâ } & \text { lap-male } & \text { shu } & \text { da } \\ \text { 1.SG.ERG-EMPH } & \text { what } & \text { speak-FUT } & \text { QP:DBT } & \text { now } \\ \text { 'Now what should I talk about?' } & & \end{array}$

'Now what should I talk about?'

This question comes from the beginning of an interview of two people. Prior to the beginning of the recording, we discussed what the topic of the interview would be. One speaker would ask questions to the other speaker about rice cultivation and related farming practices in the village and the other speaker would answer. The speaker of (20) knew the topic but uttered (20) before starting. She did not wait for a reply; she simply posed the question out loud and then moved on to the discussion.

A similar example is shown in (21), which was overheard inside a villager's home:

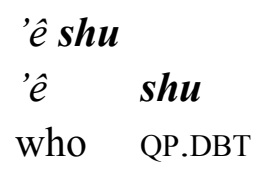

'Who is it?'

This question was uttered by the housewife upon hearing the door open to the house and someone enter. She did not direct the question at anyone in particular but rather was almost thinking aloud, wondering who it could be.

The above two examples show questions that could, arguably, not be directed at a particular interlocutor. However, in my experience $s h u$ 'QP.DBT' is also used with interlocutors. For example, we spent a few days walking through the forests identifying plant names and uses. Most of this data collection was conducted in the Kurtöp language. I asked villagers the various names and uses of nearly every plant I saw, but realized after some time that I was making the villagers uncomfortable. It was only after this experience and through discussion with consultants that I discovered I was using the wrong question construction. The villagers were not expected to be able to identify all the plants in the forest, but my direct questioning implied I did 
expect them to be able to. In that instance, I was told I should have been using the form shu 'QP.DBT'.

\section{$6 \quad$ Summary and Conclusions}

Kurtöp speakers take into account their expectations of other's knowledge in perfective aspect, in tags, and when asking questions. In other words, in some grammatical contexts, they are required to anticipate the state of knowledge of their interlocutor. In perfective aspect, the relevant suffixes, -shang and -pala are used when speakers are certain, have direct evidence, and when the event was not unexpected. The primary contrast between the two forms appears to be one of speaker access to knowledge. If the speaker has privileged access to knowledge the form -shang is selected; otherwise - pala is used. Thus, the speaker has to take into account the knowledge state of the interlocutor, as well as that of other people. If the knowledge is privileged to speaker, and thus new to the interlocutor, the form -shang will be used; -shang is not used when the interlocutor already shares the knowledge. Similarly, we saw a two-way contrast in tag particles. The tag $=w u$ is used when speakers expect the interlocutor to share the knowledge while $=m i$ is reserved for contexts when the information is new for the interlocutor. The final forms discussed were question particles. A set of forms are used for the default scenario, when the speaker expects the hearer to have the answer to the question. However, the form shu should be used for those contexts when speakers do not expect hearers to have the answer. Table 2 presents these contrasts in light of some of the related categories in the language.

\begin{tabular}{|c|c|c|c|}
\hline & $\begin{array}{l}\text { Expectation of interlocutor } \\
\text { knowledge }\end{array}$ & $\begin{array}{l}\text { Unexpected } \\
\text { (mirativity) }\end{array}$ & Evidentiality \\
\hline \multirow[t]{2}{*}{ Tense/Aspect } & $\begin{array}{l}\text {-shang (hearer unexpected to } \\
\text { share knowledge) }\end{array}$ & $\begin{array}{l}\text { - } \boldsymbol{n a} \text { (information } \\
\text { unexpected) }\end{array}$ & $-m u$ (indirect source) \\
\hline & $\begin{array}{l}\text {-pala (hearer not unexpected to } \\
\text { share knowledge) }\end{array}$ & $\begin{array}{l}\text { - ta (information } \\
\text { unexpected) }\end{array}$ & \\
\hline Particles & $\begin{array}{l}\text { shu (hearer unexpected to } \\
\text { share knowledge) }\end{array}$ & & \\
\hline \multirow{3}{*}{ Clitics } & & & $=r i($ oral source $)$ \\
\hline & $\begin{array}{l}=\boldsymbol{m i} \text { (hearer unexpected to } \\
\text { share knowledge) }\end{array}$ & & \\
\hline & $\begin{array}{l}=\boldsymbol{w} \boldsymbol{u} \text { (hearer expected to share } \\
\text { knowledge) }\end{array}$ & & \\
\hline
\end{tabular}

Table 2. Kurtöp markers of interlocutor expectation in the larger grammar of knowledge context (cf. Hyslop 2014a)

The category of speaker expectation of interlocutor knowledge is a category that is separate from evidentiality or mirativity. These two categories are also present in Kurtöp but are 
clearly distinct. Evidentiality is concerned with speaker source of knowledge. In Kurtöp, evidentials are used to mark that a speaker gained his/her knowledge through inference or through hearsay. Mirativity is concerned with speaker expectation of knowledge. The Kurtöp mirative is employed when the speaker or actor reports on knowledge that was unexpected or new to $\mathrm{him} / \mathrm{her}$. The contrast made via the choice of -shang versus - pala, $=w u$ versus $=m i$ and $y o$ or $y a$ versus shu is different; rather, in choosing between these options, the speaker must take into account the state of knowledge of the interlocutor. Note that the nuances of use in each of these contexts is slightly different. In perfective aspect, it appears the primary contrast between -shang and -pala is one of speaker's exclusive access to knowledge; expectation of interlocutor falls out from the contrast. With the questions, the dubiative question particle $s h u$ is also used with rhetorical questions, when an argument can be made that there is no interlocutor at all. It is perhaps only with the tags that the core and unarguable contrast is made between those contexts in which the speaker believes the interlocutor shares his/her knowledge and those contexts in which the speaker believes the knowledge is new to his/her interlocutor.

No doubt speaker expectation of interlocutor knowledge is an integral facet of human language. As speakers of any language, we take it for granted that we consider where our interlocutor is coming from (though some are arguably better than others at this). Surely several grammatical constructions or intonation patterns come together in any language in order to tend to speaker expectation of interlocutor knowledge. However, this contrast has been grammaticalized in Kurtöp.

Research on "shared" or "common" ground or "territories of knowledge" also addresses this topic (see e.g. Heritage 2012; Kamio 1994) as does the idea of "epistemic intersubjectivity" and, to some extent, "multiple perspective" (Evans 2004). Similar phenomena have been reported in unrelated languages, including the Panoan language Kakataibo (Zariquey 2014), the Bolivian isolate Yurakaré (Gipper 2011), and the Papuan language Mee (Niko Kobepa, pc). At present, I hesitate to introduce a new name for the category until we have more examples from more languages. Let it suffice for our present purposes to have illustrated the category with some data from Kurtöp. As more data from more languages become available, no doubt the nature of the category will become clearer.

\section{References}

Aikhenvald, Alexandra Y. 2004. Evidentiality. Oxford University Press. http://eprints.jcu.edu.au/9634/.

DeLancey, Scott. 1997. Mirativity: The Grammatical Marking of Unexpected Information. Linguistic Typology 1: 33-52.

Evans, Nicholas. 2004. "View with a View: Towards a Typology of Multiple Perspective Constructions." In Proceedings from BLS 30, 1:93-120. Berkeley, CA: University of California.

Gipper, Sonja. 2011. "Evidentiality and Intersubjectivity in Yurakaré: An Interactional Account. PhD Dissertation, Radboud Universiteit Nijmegen. 
Heritage, John. 2012. The Epistemic Engine: Sequence Organization and Territories of Knowledge. Research on Language \& Social Interaction 45(1): 30-52. doi:10.1080/08351813.2012.646685.

Hyslop, Gwendolyn. 2011a. A Grammar of Kurtöp. PhD Dissertation, Eugene, OR: University of Oregon.

Hyslop, Gwendolyn. 2011b. Mirativity in Kurtöp. Journal of South Asian Linguistics 4 (1): $43-$ 60.

Hyslop, Gwendolyn. 2014a. Grammar of Knowledge in Kurtöp: Evidentiality, Mirativity, and Expectation of Knowledge. In Alexandra Aikhenvald and R. M. W. Dixon, eds., The Grammar of Knowledge, pp. 108-131. Oxford: Oxford University Press.

Hyslop, Gwendolyn. 2014b. A Preliminary Reconstruction of East Bodish. In Nathan Hill and Thomas Owen-Smith, eds. Trans-Himalayan Linguistics, pp. 155-179. Berlin: Mouton de Gruyter.

Hyslop, Gwendolyn. to appear. On Mirativity and Egophoricity in Kurtöp. In Elisabeth Norcliffe, Lila San Roque, and Simeon Floyd, eds. Egophoricity. Amsterdam: John Benjamins.

Kamio, Akio. 1994. The Theory of Territory of Information: The Case of Japanese. Journal of Pragmatics 21: 67-100.

Tournadre, Nicolas. 2008. Against the Concept of 'Conjunct'/'Disjunct' in Tibetan. In Brigitte Huber, Marianne Volkart, Paul Widmer, and Peter Schwieger, eds. Chomolangma, Demawend Und Kasbek, Festschrift Für Roland Bielmeier, pp 281-308. Halle: International Institute for Tibetan and Buddhist Studies GmbH. 